\title{
A Materialist and Standpoint Critique of Social Movements' Theoretical Presumptions
}

\author{
Robert F. Carley ${ }^{1}$
}

This paper explores a selective intellectual historiography in contemporary social movements scholarship and offers a critique of it. I argue that although the study of social movements, especially in the context of globalization, is inherently about capital, modernity and forms of political, social, and economic agency, social movement scholarship has retreated from the materialist influence upon their analysis. As a result, breaking connections with a Marxist materialist approach has made it difficult for social movement scholars, in the social sciences to have a standpoint: this is detrimental for both the politics of social movement studies but, also, for critique. [Article copies available for a fee from The Transformative Studies Institute. E-mail address: journal@transformativestudies.org Website: http://www.transformativestudies.org (C2019 by The Transformative Studies Institute. All rights reserved.]

KEYWORDS: Social Movement Studies, Gramsci, Marxism, Moral Economy, Framing, Neoliberalism.

In this paper I discuss the specific ramifications of presumptions and knowledge in the social sciences. Breaking connections with a Marxist materialist approach has also lead, in specific, to "process" concepts that in attempting to describe like phenomena are empirically dubious: they prescribe actions, events, and effects which require analysis. In other words, some concepts and theories presume things of social movement

\footnotetext{
${ }^{1}$ Robert F. Carley, Ph.D., is Assistant Professor of International Studies at Texas A\&M University, College Station. He serves on the editorial board of Sociological Focus, the steering committee of The Union for Democratic Communications, and, as Book Review Editor, is a member of the Editorial Collective of Lateral: Journal of the Cultural Studies Association. He has recently completed a book manuscript tentatively titled, Culture and Tactics: Gramsci, Race, and The Politics of Interpretation. In the last year he published Collectivities: Politics at the Intersections of Disciplines (2016) and received The North Central Sociological Association's 2017 Scholarly Achievement Award. Address correspondence to: Robert Carley, Texas A\&M University, Department of International Studies, College Station, Texas; e-mail: carley@tamu.edu.
} 